\title{
Spatial genetic structure of the sea sandwort (Honckenya peploides) on Surtsey: an immigrant's journey
}

\author{
S. H. Árnason ${ }^{1}$, E. Th. Thórsson ${ }^{1}$, B. Magnússon ${ }^{2}$, M. Philipp ${ }^{3}$, H. Adsersen ${ }^{3}$, and K. Anamthawat-Jónsson ${ }^{1}$ \\ ${ }^{1}$ Institute of Life and Environmental Sciences, University of Iceland, Askja, Sturlugata 7, Reykjavík, IS-101, Iceland \\ ${ }^{2}$ Icelandic Institute of Natural History, Urridaholtsstraeti 6-8, Gardabær, IS-220, Iceland \\ ${ }^{3}$ Department of Biology, University of Copenhagen, Universitetsparken 15, 2100 Copenhagen $\varnothing$, Denmark
}

Correspondence to: K. Anamthawat-Jónsson (kesara@hi.is)

Received: 6 April 2014 - Published in Biogeosciences Discuss.: 27 June 2014

Revised: 18 September 2014 - Accepted: 30 September 2014 - Published: 29 November 2014

\begin{abstract}
Sea sandwort (Honckenya peploides) was one of the first plants to successfully colonize and reproduce on the volcanic island Surtsey, formed in 1963 off the southern coast of Iceland. Using amplified fragment length polymorphic (AFLP) markers, we examined levels of genetic variation and differentiation among populations of $H$. peploides on Surtsey in relation to populations on the nearby island Heimaey and from the southern coast of Iceland. Selected populations from Denmark and Greenland were used for comparison. In addition, we tested whether the effects of isolation by distance could be seen in the Surtsey populations. Using two primer combinations, we obtained 173 AFLP markers from a total of 347 plant samples. The resulting binary matrix was then analysed statistically. The main results include the following: (i) Surtsey had the highest proportion of polymorphic markers as well as a comparatively high genetic diversity (55.5\% proportion of polymorphic loci, PLP; 0.1974 $H_{\mathrm{E}}$ ) and Denmark the lowest (31.8\% PLP; $0.132 H_{\mathrm{E}}$ ), indicating rapid expansion during an early stage of population establishment on Surtsey and/or multiple origins of immigrants; (ii) the total genetic differentiation $\left(F_{\mathrm{ST}}\right)$ among Surtsey (0.0714) and Heimaey (0.055) populations was less than half of that found among the mainland populations in Iceland (0.1747), indicating substantial gene flow on the islands; (iii) most of the genetic variation $(79 \%, p<0.001)$ was found within localities, possibly due to the outcrossing and subdioecious nature of the species; (iv) a significant genetic distance was found within Surtsey, among sites, and this appeared to correlate with the age of plant colonization; and (v) the genetic structure analysis indicated multiple coloniza-
\end{abstract}

tion episodes on Surtsey, whereby H. peploides most likely immigrated from the nearby island of Heimaey and directly from the southern coast of Iceland.

\section{Introduction}

On the 14th of November 1963, just $30 \mathrm{~km}$ off the southern coast of Iceland, the island of Surtsey was born. Surtsey surfaced from the North Atlantic Ocean during almost four years (1963-1967) of intermittent spewing of volcanic material from the Mid-Atlantic Ridge at $63^{\circ} 18^{\prime} 22^{\prime \prime} \mathrm{N}$, $20^{\circ} 36^{\prime} 5^{\prime \prime} \mathrm{W}$, just $5 \mathrm{~km}$ south-west of Geirfuglasker, the southernmost island in the Vestmannaeyjar archipelago (Thórarinsson, 1966). During the first survey of the island on 21 May 1964, plant seeds were already documented having washed up on shore (Einarsson, 1965). It seems almost certain that the first plants to arrive on the island grew from seeds drifting with sea currents to the island, as seedlings of the first colonizers, i.e. Cakile edentula, Leymus arenarius, Honckenya peploides and Mertensia maritima, were found growing at the high tide line (Einarsson, 1968; Fridriksson and Johnsen, 1968; Fridriksson, 1970).

The recent geologic origin and meticulously welldocumented history of colonization on Surtsey provide an unprecedented opportunity to study the birth, coming of age and decline of a small, relatively isolated oceanic volcanic island ecosystem by natural means, devoid of all human influence. The study species, Honckenya peploides, was first recorded on the island in 1967 with 26 individuals 
(Fridriksson and Johnsen, 1968). The plants survived the first winter (Fridriksson, 1970) and by 1968 there were 103 individuals; by 1971 the number was reduced to 52 , five of which flowered, with one producing seed. In 1972, 71 plants were recorded, then a major colonization event took place and in the following summer a total of $548 \mathrm{H}$. peploides individuals were recorded indicating the first episode of seedlings produced on the island. The species has since grown on to dominate the vegetation of most sandy habitats on the island to this day (Magnússon et al., 2009 and 2014).

Isolated oceanic islands have long been thought of as natural laboratories for the study of evolutionary processes (MacArthur and Wilson, 1967). Making up only $5 \%$ of the earth's land area, islands are estimated to include roughly $20 \%$ of all known vascular plant species as well as $15 \%$ of all known mammal, bird and amphibian species (Brooks, 2006). Newly formed oceanic islands as well as areas recently affected by cataclysmic events such as volcanic eruptions present scientists with the opportunity to collect data and analyse evolutionary processes at spatial and temporal scales not possible with ecosystems in higher successional stages (Fridriksson and Magnússon, 1992; Whittaker et al., 2008; Tsuyuzaki 2009). Due to the relative isolation and novel ecological niches that such areas provide, colonization by small populations often leads to rapid evolutionary change, adaptive radiation and speciation (Cody and Overton, 1996; Savolainen et al., 2006; Buerki et al., 2013). Such radiations are thought to be a result of mutational spread under different selection pressures as well as allele fixation and differential survival of genotypes best suited for the particular environment (see e.g. Barton and Mallet, 1996).

Genetic variation is the cornerstone of evolution; without it, adaptation and survival of the biota would cease to be possible. The distribution and segregation of current variation is thought to be a reflection of the history of populations through time. Reduced variation within a population due to inbreeding and increased homozygosity can lead to loss of fitness or evolutionary potential and in the most extreme cases causing species depression and extinction (Charlesworth and Charlesworth, 1987; Frankham, 1998; Triantis et al., 2010; Alsos et al., 2012). Jaenike (1973) proposes that isolation along with limited area should affect genetic variation of populations on islands in a similar way as it does species diversity (MacArthur and Wilson, 1967). That is, as island distance from larger landmasses increases, species number (or genetic diversity) decreases due to the effect of distance on immigration. This diversity tends to decrease as island size decreases due to the heightened probability of extinction. Frankham (1997) supports this theory, showing that many taxa on islands have significantly lower genetic variation than the same mainland species, with the effect increasing with decreasing island size. Diversity is not only affected by island size and isolation, but also by island age. According to the general dynamic model (GDM) of oceanic island biogeography (Whittaker et al., 2008), a loss of physical and topographic complexity together with an increase in biotic interactions and competition can lead to a decline in species richness or diversity as an island ages. In this context the young island of Surtsey provides an ideal environment, both spatially and temporally, to test whether the ecological opportunity provided by the vacant niche space on the island can have a positive effect on the genetic diversity of colonizing species. Most studies to date however, involve old islands, which presumably are in the declining phase of the diversity curve.

Studies on oceanic islands have shown that colonizing plant species that experience founder effects and/or bottlenecks tend to show reduced genetic diversity (e.g. Westerbergh and Saura, 1994; Affre et al., 1997; Yamada and Maki, 2012). However, reduction in genetic diversity following island colonization is not always the case. Some plant invaders show diversity gain, a potential influence of mating systems (Sakai et al., 2001; Fernández-Mazuecos and Vargas, 2011). Although in general there are significant losses of both allelic richness and heterozygosity in introduced populations, and large gains in diversity are rare, multiple introductions have been shown to rescue the losses in diversity in a wide range of plant, animal and fungal taxa (reviewed in Dlugosch and Parker, 2008). Genetic diversity or allelic variation also appears to increase over long timescales, suggesting that gene flow plays a role in augmenting diversity over the long-term (e.g. Désamoré et al., 2012). Gene flow between formerly differentiated populations, i.e. via hybridization, has been shown to result in levels of diversity that exceed those in the source populations (Novak and Mack, 1993; Ellstrand and Schierenbeck, 2000). Numerous factors such as time, isolation by distance, breeding systems, dispersal ability and polyploidy all have a dynamic interplay, resulting in differences in genetic behaviour and variation depending on the organism in question.

In the present study, amplified fragment length polymorphism (AFLP) data along with classical and Bayesian statistical methods were used to deduce the genetic structure of Honckenya peploides colonizing Surtsey. Due to the fact that plant colonization and succession have been thoroughly studied there since its inception (Fridriksson and Johnsen, 1968; Fridriksson, 1970; Magnússon et al., 2009), and the fact that $H$. peploides was one of the first and most prolific colonizers of the island, Surtsey provides the perfect natural laboratory for a study of this type and $H$. peploides a good model species. The objectives of this study were to assess the genetic diversity and population genetic structure of $H$. peploides on the island of Surtsey and to compare it to the genetic structure on older, more established locations on Heimaey Island, mainland Iceland, Denmark and Greenland. 


\section{Materials and methods}

\subsection{Study species}

Honckenya peploides (L.) Ehrh. (Caryophyllaceae) is a gynodioecious, perennial, maritime dicot and can reproduce both asexually using its rhizomatous system and sexually with female (pistillate) and hermaphrodite (pollen producing morph) flowers (Malling, 1957). Asexual reproduction via rhizomes results in daughter clones which emerge as shoots through the sand from the overwintering buds. These shoots often remain attached to parent clones, with connections sometimes running up to $2 \mathrm{~m}$ from the parent plant (Sánchez-Vilas et al., 2010; Baillie, 2012). Seeds of hermaphrodites develop into female and hermaphrodite plants in an approximate $1: 3$ ratio, whereas seeds of female flowers produce about as many hermaphrodites as females (Malling, 1957). The sex determination system in $H$. peploides is therefore considered heterogamous for the hermaphrodite. Among most male heterogamous subdioecious species, hermaphrodites rarely produce seeds and when they do, the number and the fitness of seeds is very low compared to female flowers, possibly indicating some level of inbreeding depression (Tsukui and Sugawara, 1992; Keller and Schwaegerle, 2006; Baillie, 2012).

The habitat of $H$. peploides is mainly limited to dunes, drift lines, lakeshores and seashores. It has a circumpolar distribution extending from the Arctic to the temperate zone in western Europe, North America and north-eastern Russia down to Japan (Hultén, 1968; Hultén and Fries, 1986). The plant is an early colonizer, contributing to the anchorage of the soil and was the first plant to set seed on Surtsey only a few years after the island first appeared.

\subsection{Marker choice}

Amplified fragment length polymorphism (AFLP), a selectively neutral, highly polymorphic technique, combines restriction digestion and polymerase chain reaction (PCR) to produce Mendelian-inherited, multilocus, dominant markers which are highly reproducible (Vos et al., 1995). The method quickly generates large numbers of markers; prior knowledge of the genomic sequence in question is not necessary; and very little starting template is required and it can be used for most organisms. AFLP fingerprinting is an established molecular marker with broad applications in population genetics, phylogenetics, linkage mapping and parentage analyses (Powell et al., 1996; Meudt and Clarke, 2007; Foll et al., 2010; Poczai et al., 2013). The technique has been used to evaluate patterns of genetic variation and genetic structure in a number of Arctic, subarctic and Antarctic plant species as well as isolated island plant populations (Holderegger et al., 2003; Schönswetter et al., 2005; Alsos et al., 2012; Eidesen et al., 2013). AFLP has also been effectively used to detect
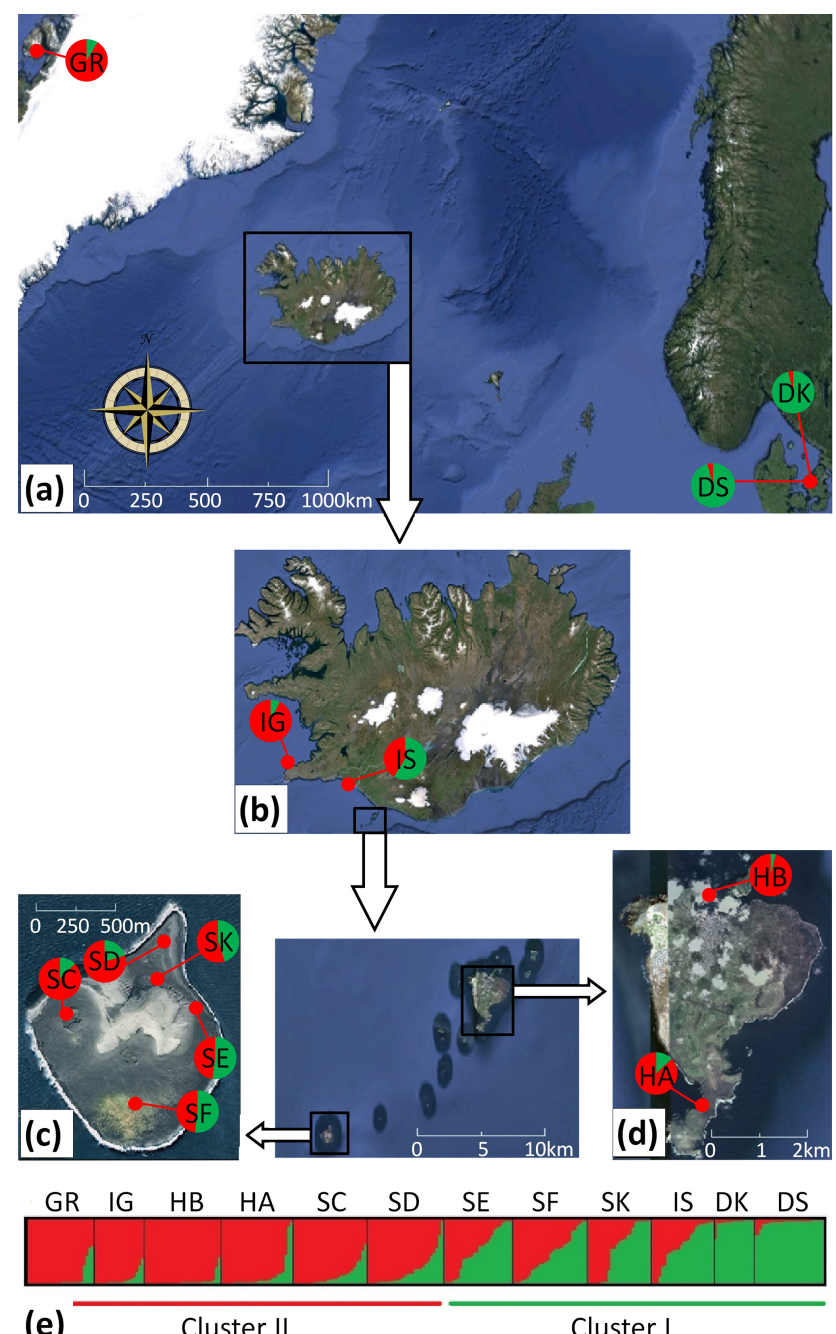

(e)

Cluster II

Cluster I

Figure 1. Bayesian inference clustering based on AFLP results using the admixture ancestral model in STRUCTURE software. For the full AFLP data set, the model $K=2$ produced the highest $\Delta K$ value, hence two groups assigned in red versus green. The two genetic groups detected are represented as pie charts on the Google Earth maps of the following: (a) all sampling locations, (b) Iceland, (c) Surtsey and (d) Heimaey. An alignment based on proportion between the two genetic groups in each population (e) reveals two clusters, I and II, whereby Denmark populations (DK \& DS) predominate Cluster-I (green) and Greenland (GR) at the opposite end in Cluster-II (red). Population names are abbreviated as in Table 1.

genetic structure in the species under study, Honckenya peploides (Sánchez-Vilas et al., 2010).

\subsection{Plant material and collection locations}

During July 2010 and May 2011, a total of 397 samples were collected, from which 347 samples from 12 locations in the North Atlantic region were analysed (Table 1, see also Fig. 1). The five locations on Surtsey are as follows: SC located inside the western crater Surtungur at $70 \mathrm{~m}$ a.s.l., 
Table 1. Sampling locations, GPS coordinates, collection dates, IDs and number of samples.

\begin{tabular}{lllll}
\hline Locality & GPS Coordinates & Date & Sample ID & $N$ \\
\hline Surtsey & $63^{\circ} 18.24^{\prime} \mathrm{N}, 20^{\circ} 36.75^{\prime} \mathrm{W}$ & 12-15 Jul 2010 & SC 1-30 & 30 \\
Surtsey & $63^{\circ} 18.50^{\prime} \mathrm{N}, 20^{\circ} 35.98^{\prime} \mathrm{W}$ & 12-15 Jul 2010 & SD 1-30 & 30 \\
Surtsey & $63^{\circ} 18.19^{\prime} \mathrm{N}, 20^{\circ} 35.98^{\prime} \mathrm{W}$ & 12-15 Jul 2010 & SE 1-30 & 30 \\
Surtsey & $63^{\circ} 17.94^{\prime} \mathrm{N}, 20^{\circ} 36.34^{\prime} \mathrm{W}$ & 12-15 Jul 2010 & SF 1-30 & 30 \\
Surtsey & $63^{\circ} 18.416^{\prime} \mathrm{N}, 20^{\circ} 36^{\prime} \mathrm{W}$ & 12-15 Jul 2010 & SK 1-30 & 30 \\
Heimaey & $63^{\circ} 24.50^{\prime} \mathrm{N}, 20^{\circ} 16.79^{\prime} \mathrm{W}$ & 9 Jul 2010 & HA (1-12) (16-30) & 27 \\
Heimaey & $63^{\circ} 26.91^{\prime} \mathrm{N}, 20^{\circ} 16.25^{\prime} \mathrm{W}$ & 9 Jul 2010 & HB 1-30 & 30 \\
Gardur & $63^{\circ} 50.37^{\prime} \mathrm{N}, 21^{\circ} 04.63^{\prime} \mathrm{W}$ & 17 Jul 2010 & IG $(1-12)(16-27)$ & 24 \\
Stokkseyri & $64^{\circ} 04.96^{\prime} \mathrm{N}, 22^{\circ} 41.54^{\prime} \mathrm{W}$ & 17 Jul 2010 & IS $(1-6)(10-30)$ & 27 \\
Qeqertarsuaq & $55^{\circ} 58^{\prime} \mathrm{N}, 11^{\circ} 46^{\prime} \mathrm{E}$ & 25 Jul 2010 & GR 1-29 & 29 \\
Knarbo & $55^{\circ} 50^{\prime} \mathrm{N}, 11^{\circ} 22^{\prime} \mathrm{E}$ & 15 May 2011 & DK 1-30 & 30 \\
Skansehage & $69^{\circ} 15^{\prime} \mathrm{N}, 53^{\circ} 30^{\prime} \mathrm{W}$ & 15 May 2011 & DS 1-30 & 30 \\
\hline
\end{tabular}

growing on volcanic cinder; SD - located on the northern sand spit at $16 \mathrm{~m}$, growing on volcanic sand; $\mathrm{SE}$ - located on the eastern slope at $104 \mathrm{~m}$, growing on volcanic cinder and gravel; $\mathrm{SF}$ - located in the colonies of sea birds (mainly gulls) on the southern lava at $25-45 \mathrm{~m}$; and SK - located on the steep east-facing slope of the old tephra crater Surtur leading to the northern sandbar at $36 \mathrm{~m}$, growing on volcanic tuff and gravel. The two locations on Heimaey, the largest of the Vestmannaeyjar archipelago were as follows: HA - located on the south side of the island, growing on volcanic sand and gravel at 1-3 m; and $\mathrm{HB}$ - located on the northern side of the island by the main harbour, growing on volcanic sand and gravel at $1-2 \mathrm{~m}$. The two locations on mainland Iceland were as follows: Stokkseyri (IS) - located at the end of a fresh water marsh in between two large glacial rivers at 1-3 m on the southern coast, growing on glacial deposits and fine sand; and Gardur (IG) - located at the western-most tip of the Reykjanes peninsula at $1-3 \mathrm{~m}$, growing on a rocky coast. The two locations in Denmark were as follows: Skansehage (DS) - located on the north-eastern tip of the island of Sjælland at $1-3 \mathrm{~m}$, growing above the high tide line on a limestone sand beach; and Knarbo (DK) - also located on the island of Sjælland in a very similar habitat at $1-3 \mathrm{~m}$. The one location in Greenland was Qeqertarsuaq (GR) - located on the south coast of Disko Island on the west coast of Greenland at $1-3 \mathrm{~m}$, growing on rocky seashore in glacial till.

Samples were collected by placing a marker in a random location surrounded by clumps of $H$. peploides and sampling clumps within a $20 \mathrm{~m}$ radius of the marker. At each locality 30 spatially segregated clumps were sampled, avoiding resampling of clones as best as possible. Fresh leaf samples were collected and stored in plastic bags with silica beads until further laboratory analysis could be conducted.
Table 2. Primers used in the study (Applied Biosystems).

\begin{tabular}{ll}
\hline Primer Name & Primer Sequence \\
\hline EcoRI & 5'-fam-GAC TGC GTA CCA ATT CAC T-3' \\
EcoRI & 5'-joe- GAC TGC GTA CCA ATT CAG G-3' \\
MseI & 5'-GAT GAG TCC TGA GTA ACT A-3' \\
$M s e I$ & 5'-GAT GAG TCC TGA GTA ACT C-3' \\
\hline
\end{tabular}

\subsection{DNA extraction}

Genomic DNA was extracted from dehydrated leaf tissue in a similar manner as conducted in Thórsson et al. (2010). The extraction buffer ( $2 \%$ CTAB, $1.4 \mathrm{M} \mathrm{NaCl}, 20 \mathrm{mM}$ EDTA, $100 \mathrm{mM}$ TrisHCl, $\mathrm{pH} 8$, and $0.2 \%$ 2-mercaptoethanol) was pre-warmed to $65^{\circ} \mathrm{C}$. From each individual plant, approximately $15-20 \mathrm{mg}$ of dried leaf tissue was placed in $1.5 \mathrm{~mL}$ microtube and manually pulverized to a fine powder with sterile plastic pestle in liquid nitrogen. Warm extraction buffer $(0.5 \mathrm{~mL})$ was then added to the tube and mixed well; this was then incubated at $65^{\circ} \mathrm{C}$ in a water bath for 1 to $2 \mathrm{~h}$ and mixed occasionally by inversion. An equal volume of chloroform : isoamyl alcohol $(24: 1)$ was then added and mixed well before centrifugation at $1400 \mathrm{rpm}$ for $10 \mathrm{~min}$. The aqueous phase was recovered and the DNA was ethanolprecipitated, washed twice with wash buffer $(76 \%$ ethanol and $10 \mathrm{mM}$ ammonium acetate), and the air-dried DNA pellet was resuspended in $200 \mu \mathrm{L}$ of $1 \mathrm{x}$ TE buffer $(10 \mathrm{mM}$ TrisHCl and $1 \mathrm{mM}$ EDTA, $\mathrm{pH} 8)$. One $\mu \mathrm{L}$ of RNase $\left(10 \mathrm{mg} \mathrm{mL}^{-1}\right)$ was added, the solution mixed well and incubated at $37^{\circ} \mathrm{C}$ for $30 \mathrm{~min}$, after which $78 \mu \mathrm{L}$ of $5 \mathrm{M} \mathrm{NaCl}$ was added, the solution mixed well by inversion. The DNA was then ethanolprecipitated again, and the DNA pellet was resuspended in $100 \mu \mathrm{L}$ of $1 \mathrm{x}$ TE buffer. Cleaned DNA samples were stored in a $-27^{\circ} \mathrm{C}$ freezer until AFLP work could be done. The quality and concentration of DNA in all samples was measured using a Thermo Scientific NanoDrop 1000 Spectrophotometer at OD 260/280 nm. 


\subsection{AFLP fingerprinting}

The AFLP technique was performed with fluorescent dye labelling and detection technology, using all AFLP reagents, adapters, primers, enzymes, size standards and fluorescent dyes from Applied Biosystems ${ }^{\circledR}$. Restriction and ligation reactions were carried out in accordance with the AFLPTM Plant Mapping Protocol (Applied Biosystems ${ }^{\circledR}$ ) for averagesized genomes. Fragment detection was performed on the ABI Prism 3730 Genetic Analyzer (Applied Biosystems ${ }^{\circledR}$ ), an automated capillary electrophoresis device. Prior screening for primers suitable for use with $H$. peploides was previously performed on plant individuals of both sexes across multiple localities (Sánchez-Vilas et al., 2010). Two primer pairs were chosen (MseI-CTA/EcoRI-ACT \& MseI$\mathrm{CTC} /$ EcoRI-AGG), and selective amplification was carried out on all samples (Table 2). Single PCRs were performed for each primer combination, and the end products from two primer pairs (with different dyes) were multiplexed for electrophoresis. In all the reactions, only the EcoRI primers were 5 ' labelled with a fluorescent dye.

A total of $250 \mathrm{ng}$ of DNA was added to a digestion-ligation mix in a final volume of $11 \mu \mathrm{L}$ containing digestion-ligation buffer ( $50 \mathrm{mM} \mathrm{NaCl}, 50 \mathrm{ng} / \mu \mathrm{L}$ BSA $), 1 \mu \mathrm{L}$ of both MseI and EcoRI adapters, 1 unit of T4 DNA ligase, 5 units of EcoRI and 1 unit of MseI and digested at $37^{\circ} \mathrm{C}$ for $2 \mathrm{~h}$. Following digestion-ligation, pre-amplification PCR was performed with EcoRI-A/MseI-C primer pairs having 1 selective nucleotide with 19 cycles of the following: $2 \mathrm{~min}$ at $72^{\circ} \mathrm{C}, 1 \mathrm{~s}$ at $94^{\circ} \mathrm{C}, 30 \mathrm{~s}$ at $56^{\circ} \mathrm{C}, 2 \mathrm{~min}$ at $72^{\circ} \mathrm{C}$, followed by a final extension for $30 \mathrm{~min}$ at $60^{\circ} \mathrm{C}$. Each $10 \mu \mathrm{L}$ of the reaction contained $2 \mu \mathrm{L}$ of the restriction/ligation dilution (1:20), $7.5 \mu \mathrm{L}$ of AFLP core mix from the Applied Biosystems ${ }^{\circledR}$ Amplification Core Mix Module (buffer, nucleotides, and AmpliTaq ${ }^{\circledR} D N A$ Polymerase) and $25 \mathrm{mM}$ of each primer pair. The PCR product was then diluted (1:20) and used for the selective amplification with two primer combinations containing three selective nucleotides (MseICTA/EcoRI-ACT and MseI-CTC/EcoRI-AGG). The selective amplification PCR reaction entailed the following: $1 \mathrm{cy}-$ cle of $2 \mathrm{~min}$ at $94^{\circ} \mathrm{C}, 30 \mathrm{~s}$ at $65^{\circ} \mathrm{C}, 2 \mathrm{~min}$ at $72^{\circ} \mathrm{C}$; $8 \mathrm{cy}$ cles of $1 \mathrm{~s}$ at $94^{\circ} \mathrm{C}, 30 \mathrm{~s}$ at $64^{\circ} \mathrm{C}$ and $2 \mathrm{~min}$ at $72^{\circ} \mathrm{C} ; 23$ cycles of $1 \mathrm{~s}$ at $94^{\circ} \mathrm{C}, 30 \mathrm{~s}$ at $56^{\circ} \mathrm{C}, 2 \mathrm{~min}$ at $72^{\circ} \mathrm{C}$; followed by a final extension for $30 \mathrm{~min}$ at $60^{\circ} \mathrm{C}$. Each $10 \mu \mathrm{L}$ of the reaction contained $1.5 \mu \mathrm{L}$ of the pre-selective amplification dilution (1:20), $7.5 \mu \mathrm{L}$ of the AFLP core mix, $0.5 \mu \mathrm{L}$ EcoRI primer at $1 \mu \mathrm{M}$ (fluorescently labelled) and $0.5 \mu \mathrm{L}$ MseI primer at $5 \mu \mathrm{M}$. For analysis using capillary electrophoresis, each $11 \mu \mathrm{L}$ reaction contained $1 \mu \mathrm{L}$ of each of the two selective amplification products, $9.5 \mu \mathrm{L}$ HiDiFormamid and $0.5 \mu \mathrm{L}$ Genescan-500 Rox-labelled internal size standard. After preparation, samples were denatured for $2 \mathrm{~min}$ at $94^{\circ} \mathrm{C}$ and chilled on ice. Capillary electrophoresis was carried out on the 3730 series DNA Analyzer using POP 7 capillary polymer and ABI Prism 3730 electrophoresis buffer.
The capillaries were $47 \mathrm{~cm}$ in length with $50 \mu \mathrm{m}$ in diameter. Samples were injected electrokinetically for $5-20 \mathrm{~s}$ at $15 \mathrm{kV}$ and were run at $15 \mathrm{kV}$ for $24 \mathrm{~min}$ at $60^{\circ} \mathrm{C}$.

\subsection{Data analysis}

\subsubsection{Raw data}

In the AFLP analysis, only amplified fragments in the $50-500$ bp range that could be scored unambiguously were included. Fragments outside this range could not be accurately sized. The raw AFLP data were scored using the program GeneMapper 3.7 (Applied Biosystems ${ }^{\circledR}$ ) and the presence or absence of each fragment was scored for each individual manually in GeneMarker ${ }^{\circledR}$ (Softgenetics). Analysis of the AFLP data was based on the phenotypic frequency at a particular locus (i.e. the proportion of individuals having a band). We applied the band-based approach due to the polyploidy nature of our study species and set the allele frequency equal to band frequency.

\subsubsection{Genetic relationships and isolation by distance}

The relationship among populations and individuals was first explored by using Nei's genetic distances (Nei, 1973) among populations estimated in AFLP-SURV 1.0 (Vekemans et al., 2002) (available at http://www.ulb.ac.be/sciences/lagev/), with distance matrices made with 10000 bootstrap ordinations. These matrices were then used to construct un-rooted neighbour joining (NJ) trees with the NEIGHBOR and CONSENSUS programs in PHYLLIP version 3.65 (Felsenstein, 1989), and the trees were graphically displayed using MEGA (Molecular Evolutionary Genetics Analysis) software version 6.06 (Tamura et al., 2013). Nei's pairwise genetic distance matrixes as well as pairwise $F_{\mathrm{ST}}$ matrices calculated with AFLP-SURV 1.0 were also plotted against geographic distances in order to test for the effects of isolation by distance. All locations in the full data set as well as selected regions and locations were compared. Significance was tested with a Mantel correlation test in $\mathrm{R}$ with the ade4 package (Chessel et al., 2004). Multidimensional scaling (Kruskal, 1964) was also used to visualize patterns of relatedness within the $F_{\mathrm{ST}}$ matrices.

\subsubsection{Bayesian clustering}

A Bayesian clustering approach, implemented in STRUCTURE 2.2 (Pritchard et al., 2000) was used to determine the number of genetic clusters $(K)$ in the data set without any prior information on the sampling locations. To assume the admixture model, the number of genetically distinct clusters $(K)$ was set to vary from 1 to 12 (total number of populations). Twenty independent simulations were run for each $K$ value with a burn-in length of $10^{4}$ and a run length of $10^{5}$ Markov chain Monte Carlo generations. The optimal value of $\mathrm{K}$ was estimated by using the R script STRUCTURE-sum- 
2009, part of AFLPDAT (Ehrich, 2006), to summarize the output files, calculate similarity coefficients between replicate runs and to plot the means of the estimated log posterior probability of the data over the replicate runs for each $\mathrm{K}$ value or $L(K)$ in order to determine the highest level of hierarchical structure (Evanno et al., 2005). After detection of genetic divergence among populations, the analysis was repeated for each group to determine if any substructure existed below the highest hierarchical level. Graphical output was generated using CLUMPP version 1.1.1 (Jakobsson and Rosenberg, 2007) and DISTRUCT (Rosenberg, 2004) software.

\subsubsection{Genetic data analysis}

Genetic differentiation among populations was calculated as Wright's $F_{\text {ST }}$ (Wright, 1965; Lynch and Milligan, 1994) in AFLP-SURV 1.0 (Vekemans et al., 2002) using 10000 permutations to test for significance. The percentage of polymorphic loci (PLP), total gene diversity $\left(H_{\mathrm{T}}\right)$, expected heterozygosity $\left(H_{\mathrm{E}}\right)$ and average gene diversity $\left(H_{\mathrm{W}}\right)$ were also estimated in AFLP-SURV. To test for significant difference in PLP and $H_{\mathrm{T}}$ between locations, a Wilcoxon rank test was implemented in R. The relationship between PLP and $H_{\mathrm{T}}$ as well as between population size and PLP or $H_{\mathrm{T}}$ was also tested with a Spearman's rank correlation test in R. Analysis of molecular variance (AMOVA) was performed to assign components of genetic variation to sets of populations defined by location in Arlequin suite version 3.5 (Excoffier and Lischer, 2010).

\section{Results}

\subsection{Patterns of polymorphism and heterozygosity}

Using two primer combinations (Table 2), 173 AFLP loci were scored across all sampling locations. Of these, 65 were polymorphic $(37.6 \%)$ and used in the analysis (Table 3 ). In general, highly reproducible AFLP patterns were obtained. An average error rate of $2.1 \%$ was estimated across the ten pilot samples for all primer pairs. This value fell below the maximum (5\%) error rate percentage accepted for good AFLP reproducibility (Pineiro et al., 2007). The proportion of polymorphic loci per population (PLP) varied from $31.8 \%$ to $55.5 \%$. The total heterozygosity $\left(H_{\mathrm{T}}\right)$ was 0.2118 . The expected heterozygosity ( $H_{\mathrm{E}}$ within populations varied from 0.1328 and 0.1397 in the Denmark locations to 0.2130 in the SK Surtsey location which had the highest heterozygosity. Heimaey south (HA) and Stokkseyri (IS) on the southern coast of Iceland showed similar values, 0.1964 and 0.1972 respectively. The average genetic diversity within the populations $\left(\mathrm{H}_{W}\right)$ was 0.1746 , but when looking at the regional values, the Denmark populations had lower average genetic diversity than all Icelandic regions.

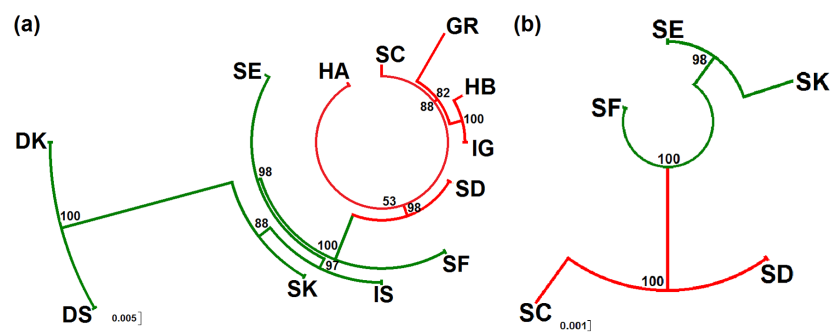

Figure 2. Un-rooted neighbour joining (NJ) trees based on Nei's genetic distances for (a) the full data set and (b) Surtsey only. Bootstrap values are shown at the nodes. Population names are abbreviated as in Table 1. The two colours, green and red, represent clusters I and II in Fig. 1, respectively.

A significant difference was found between the Denmark and Surtsey populations (Table 3) for both the PLP (31.8\% for both Denmark populations, $44.5 \%-55.5 \%$ for Surtsey populations) and the total heterozygosity $H_{\mathrm{T}}$ (Denmark $=0.1362$, Surtsey $=0.1974$ ), with $p=0.0243$ and $p=$ 0.0264 respectively. None of the other populations were found to differ significantly although PLP and $H_{\mathrm{T}}$ differed slightly among all the populations. PLP and $H_{\mathrm{T}}$ values were also moderately correlated with each other (Spearman's rank correlation, $R=0.64, p<0.05$ ) but were not correlated with population size $(\mathrm{R}=0.12$ and $R=-0.12$, respectively, $p>0.05$ ) over the whole geographic range.

\subsection{Genetic differentiation and gene diversity}

The total genetic differentiation among all 12 Honckenya peploides sampling locations was moderate $\left(F_{\mathrm{ST}}=0.1769\right.$, Table 3) but highly significant (permutation test, $P<0.001$ ) in all collection locations except Denmark (Table 4). The $F_{\mathrm{ST}}$ value for Denmark was found to be non-significant $(\mathrm{p}=0.367)$. The total $F_{\mathrm{ST}}$ among the Surtsey populations $(0.0714)$ as well as the Heimaey populations (0.0550) were less than half of that found among the mainland populations (0.1747). As seen in Table 4, the largest $F_{\mathrm{ST}}$ values were found when comparing any population with the Denmark populations (DK and DS), especially Greenland (GR: $F_{\mathrm{ST}}$ 0.4314 and 0.4400 ), Gardur (IG: $F_{\mathrm{ST}} 0.3558$ and 0.3667 ) and location SC on Surtsey $\left(F_{\mathrm{ST}} 0.3475\right.$ and 0.3567$)$.

\subsection{Bayesian analysis of genetic structure}

In the Bayesian cluster analysis obtained from STRUCTURE, the model with the highest $\Delta K$ satisfactorily explained the data obtained from the AFLP analysis (Fig. 1). In the estimated model based on the AFLP data set when $K=2$, most individuals in the Denmark (DK \& DS), Stokkseyri (IS), Surtsey E, Surtsey K and Surtsey F locations were assigned to Cluster-I; whereas most of the individuals in the Greenland (GR), Gardur (IG) in Reykjanes peninsula, Surtsey C, Surtsey D and Vestmannaeyjar Heimaey north and 
Table 3. Genetic diversity in sampling locations of Honckenya peploides. Total values are for the species, whereas subtotal values are for regions, i.e. Surtsey (SC - SK), Heimaey (HA and HB), mainland Iceland (IG and IS) and Denmark (DK and DS). PLP - percentage of polymorphic loci, $H_{\mathrm{E}}$ - expected heterozygosity, $F_{\mathrm{ST}}-$ Wright's $F_{\mathrm{ST}}, H_{\mathrm{T}}$ - total gene diversity (total heterozygosity), $H_{\mathrm{W}}-$ average gene diversity within populations.

\begin{tabular}{lcccccc}
\hline ID & Polymorphic bands & PLP & $H_{\mathrm{E}}$ & $F_{\mathrm{ST}}$ & $H_{\mathrm{T}}$ & $H_{\mathrm{W}}$ \\
\hline SC & 83 & 48 & 0.1740 & & & \\
SD & 83 & 48 & 0.1808 & & & \\
SE & 81 & 46 & 0.1789 & & & \\
SF & 77 & 44.5 & 0.1699 & & & \\
SK & 96 & 55.5 & 0.2130 & 0.0714 & 0.1974 & 0.1833 \\
HA & 86 & 49.7 & 0.1964 & & & \\
HB & 82 & 47.4 & 0.1696 & 0.0550 & 0.1938 & 0.1830 \\
IG & 78 & 45.1 & 0.1765 & & & \\
IS & 89 & 51.4 & 0.1972 & 0.1747 & 0.2265 & 0.1869 \\
DK & 55 & 31.8 & 0.1397 & & & \\
DS & 55 & 31.8 & 0.1328 & -0.0003 & 0.1362 & 0.1362 \\
GR & 76 & 43.9 & 0.1663 & & & \\
\hline Total & 65 & 37.6 & & 0.1769 & 0.2118 & 0.1746 \\
\hline
\end{tabular}

Table 4. Nei's genetic distances are displayed on the upper diagonal and $F_{\mathrm{ST}}$ values on lower diagonal (* non-significant values).

\begin{tabular}{lllllllllllll}
\hline & HA & HB & DK & DS & IG & GR & SC & SD & SE & SF & IS & SK \\
\hline HA & & 0.0132 & 0.0954 & 0.1018 & 0.0047 & 0.0194 & 0.0087 & 0.0061 & 0.0260 & 0.0176 & 0.0252 & 0.0368 \\
HB & 0.0557 & & 0.1275 & 0.1249 & 0.0062 & 0.0249 & 0.0110 & 0.0182 & 0.0500 & 0.0473 & 0.0609 & 0.0667 \\
DK & 0.3121 & 0.3962 & & $0.0000^{*}$ & 0.1091 & 0.1470 & 0.1039 & 0.0810 & 0.0587 & 0.0703 & 0.0533 & 0.0502 \\
DS & 0.3312 & 0.3981 & $0.0000^{*}$ & & 0.1115 & 0.1482 & 0.1054 & 0.0847 & 0.0699 & 0.0825 & 0.0620 & 0.0622 \\
IG & 0.0205 & 0.0285 & 0.3558 & 0.3667 & & 0.0188 & 0.0118 & 0.0182 & 0.0464 & 0.0400 & 0.0498 & 0.0580 \\
GR & 0.0804 & 0.1085 & 0.4314 & 0.4400 & 0.0828 & & 0.0201 & 0.0302 & 0.0540 & 0.0452 & 0.0595 & 0.0644 \\
SC & 0.0370 & 0.0499 & 0.3475 & 0.3567 & 0.0522 & 0.0886 & & 0.0044 & 0.0266 & 0.0238 & 0.0358 & 0.0390 \\
SD & 0.0256 & 0.0784 & 0.2906 & 0.3052 & 0.0768 & 0.1243 & 0.0199 & & 0.0154 & 0.0115 & 0.0227 & 0.0282 \\
SE & 0.1004 & 0.1881 & 0.2322 & 0.2691 & 0.1737 & 0.2015 & 0.1094 & 0.0653 & & 0.0037 & 0.0043 & 0.0077 \\
SF & 0.0728 & 0.1846 & 0.2712 & 0.3086 & 0.1579 & 0.1796 & 0.1018 & 0.0511 & 0.0171 & & 0.0050 & 0.0138 \\
IS & 0.0923 & 0.2090 & 0.2059 & 0.2357 & 0.1750 & 0.2070 & 0.1341 & 0.0882 & 0.0183 & 0.0224 & & 0.0022 \\
SK & 0.1234 & 0.2155 & 0.1891 & 0.2272 & 0.1899 & 0.2117 & 0.1384 & 0.1026 & 0.0314 & 0.0560 & 0.0088 & \\
\hline
\end{tabular}

south (HB and HA) locations were assigned to Cluster-II. No substructures were detected within any cluster as a result of further analysis (not shown here). Interestingly, the two clusters appear to be geographically divided, with Cluster-I being more eastern, with Denmark at the eastern end, and Cluster-II more western, with Greenland at the western end. Within the island Surtsey, the STRUCTURE analysis revealed a clear genetic split between those on the north-west region (SC and $\mathrm{SD}$ ) and those on the east including the southern lava (SF) and the eastern coast (SK and SE) populations. The same east-west contrast could be seen between the two Icelandic mainland populations.

\subsection{Neighbour joining (NJ) trees}

The east-west pattern revealed by the Bayesian analysis (Fig. 1) was also apparent in the neighbour joining (NJ) trees (Fig. 2) and this was supported by the multidimensional scaling (MDS) analysis (results not shown). The NJ tree based on genetic distances produced from the full data set (Fig. 2a) showed a split into two clusters: the populations DK, DS, SK, IS, SE and SF were grouped together in one cluster (the eastern Cluster-I in Fig. 1) with bootstrap values above $88 \%$, while populations GR, IG, HB, SC, HA and SD grouped together more weakly in another cluster with bootstrap values above $53 \%$ (the western Cluster-II in Fig. 1). Denmark populations were furthest away from all other locations in the genetic distance estimate. There was also a significant genetic distance between the two sites on the island of Heimaey (HA 
Table 5. Analysis of molecular variance (AMOVA). Populations are arranged into five groups according to location: (1) Denmark (DK and DS); (2) mainland Iceland (IG and IS); (3) Surtsey (SC, SD, SE, SF, SK); (4) Heimaey (HA and HB); and (5) Greenland (GR).

\begin{tabular}{llllll}
\hline Source of Variation & df & Variance & Variation $(\%)$ & Fixation Index & $P$ \\
\hline Among five geographic groups & 4 & 3.2390 & 17.40 & $F_{\mathrm{CT}}=0.1740$ & $<0.01$ \\
Among populations within group & 7 & 1.0404 & 5.59 & $F_{\mathrm{SC}}=0.0677$ & $<0.001$ \\
Within population & 288 & 14.3332 & 77.01 & $F_{\mathrm{ST}}=0.2299$ & $<0.001$ \\
Total & 299 & 18.6126 & 100 & & \\
\hline
\end{tabular}

vs. HB) and between the two sites on the southern coast of Iceland (IS vs. IG). The Greenland population fell within the western cluster. The NJ tree based on genetic distances produced from the Surtsey data set (Fig. 2b) also showed a split into two clusters, supported by bootstrap values over $98 \%$, in which the populations on the north-west side of the island $(\mathrm{SC}$ and $\mathrm{SD}$ ) clustered together (Nei's distance $=0.0044$ ) and were clearly separated (Nei's distance $=0.0115$ ) from the populations located on the south in the gull colony (SF) and the east side of the island (SE and SK).

\subsection{Mantel test - isolation by distance}

A mantel test on the full data set (not shown) revealed a positive and significant association between Nei's genetic distance and geographic distance $(r=0.6331, p=0.001)$ as well as genetic differentiation $\left(F_{\mathrm{ST}}\right)$ and geographic distance $(r=0.8083, p=0.001)$. This indicated isolation by distance (IBD) with geographic distance, explaining roughly $80 \%$ of the variation in genetic differentiation. This IBD effect was statistically significant when comparing between Iceland and Greenland (within a distance of $1500 \mathrm{~km}$ ), between Denmark and Iceland (within a distance of $2000 \mathrm{~km}$ ) and between Denmark and Greenland.

However, when the populations within each Iceland region were compared (Fig. 3), non-significant associations were obtained between genetic distance (Nei's) or genetic differentiation $\left(F_{\mathrm{ST}}\right)$ and geographic distance. This indicated that there is significant gene flow and a limited effect of isolation by distance at the regional and local scale. Considering populations on Surtsey, Heimaey and mainland Iceland together (within a distance of $150 \mathrm{~km}$ or so), non-significant associations were obtained both between Nei's genetic distance and geographic distance (Fig. 3a: $r=0.1170, p=0.279$ ) as well as between genetic differentiation $\left(F_{\mathrm{ST}}\right)$ and geographic distance (Fig. 3c: $r=0.1123, p=0.249$ ). Within the island of Surtsey, there appeared to be a negative yet nonsignificant correlation between geographic and genetic distances (Fig. 3b: $r=-0.2766, p=0.784$ ) and between genetic differentiation $\left(F_{\mathrm{ST}}\right)$ and geographic distance (Fig. 3d: $r=-0.2110, p=0.694)$. Although not statistically significant, this is of great interest as negative spatial correlations could be indicative of a pattern of dissimilar values (genotypes) appearing in close spatial association, a pattern also seen in the STRUCTURE analysis (Fig. 1) as well as the NJ tree (Fig. 2).

\subsection{Analysis of molecular variance (AMOVA)}

The AMOVA (Table 5) showed that variation within populations (sampling locations) accounted for most $(77.01 \%)$ of the genetic variance. Variation among groups (areas or regions) accounted for $17.40 \%$ of the total genetic variance and variation among populations (sampling locations) within groups (areas or regions) accounted for only $5.59 \%$. Genetic differentiation among groups was significant $(p<0.01)$ and highly significant among populations within groups as well as within populations $(p<0.001)$.

\section{Discussion}

\subsection{Patterns of diversity on Surtsey versus other sites}

The highest genetic diversity found in the present study was from Surtsey. Contrary to original expectations, genetic diversity $\left(H_{\mathrm{E}}\right)$ was found to be significantly higher in the Surtsey and Iceland populations than in the Denmark populations. Furthermore, when compared within Iceland, genetic diversity remained quite similar and was even increased in some Surtsey populations. The greater population size, age and wider geographic range of $H$. peploides in both Iceland and Denmark was expected to lead to higher genetic variation in those areas (according to Nei et al., 1975). However, the findings of this study contradict this and cast some doubt on the long-held view that genetic diversity is generally lower in island populations (Wright, 1940; Husband and Barrett, 1991; Franks, 2010). The present study revealed the same trend as in the earlier study of $H$. peploides by Eithun (2003), where multilocus genotypes (MLG) based on isozyme data were found to be more frequent in Greenland (66 MLG) and Svalbard (73 MLG) than in plants collected on the mainland in southern Norway (4 MLG). Furthermore, the present results, in parallel with a growing number of studies, find either similar (Su et al., 2010) or greater (FernándezMazuecos and Vargas, 2011; Désamoré et al., 2012) genetic diversity in oceanic island species when comparing them to their mainland counterparts. We therefore postulate that the 

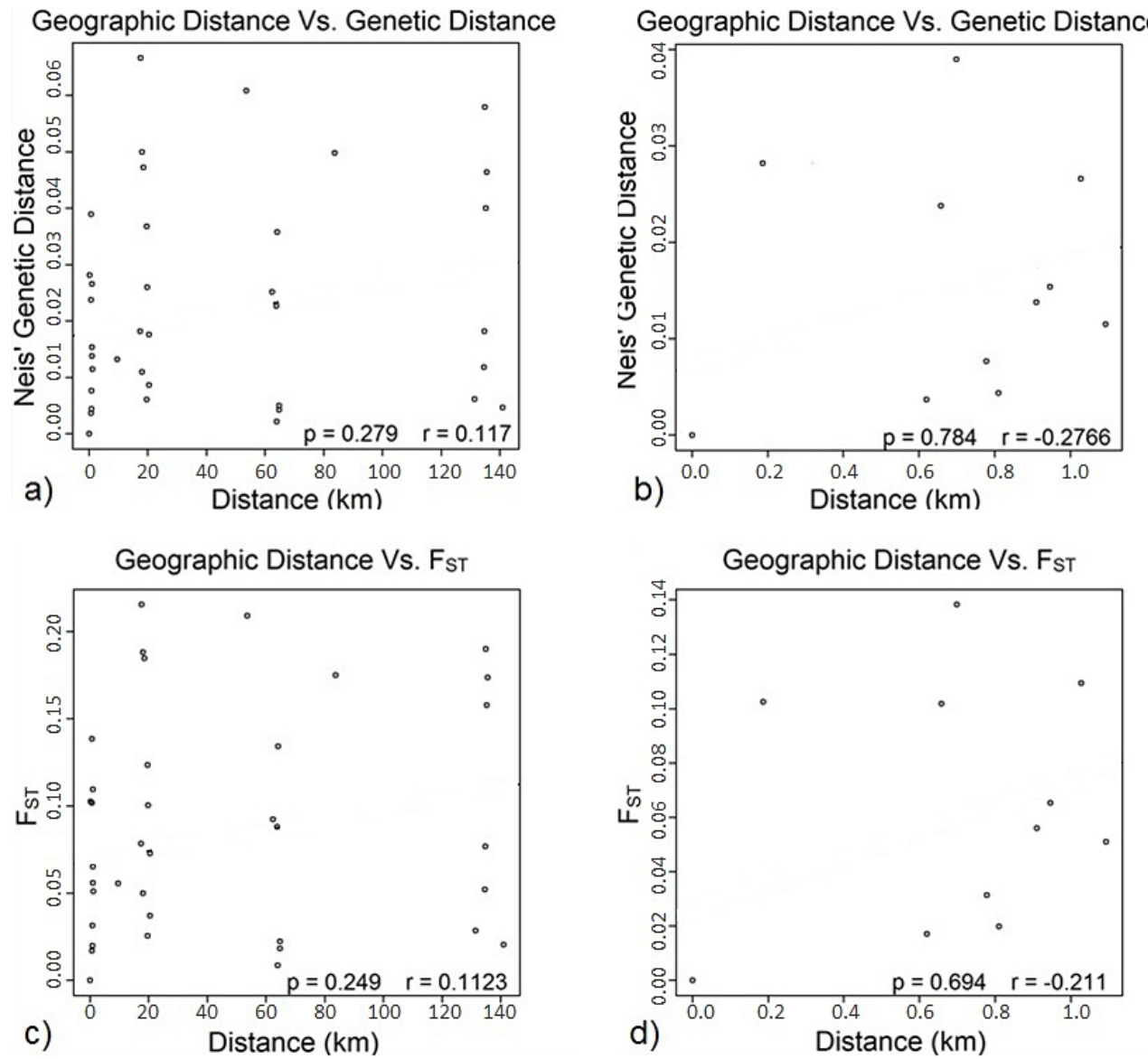

Figure 3. Isolation by distance: plots of pairwise estimates of Nei's genetic distance (top row: a and b) and $F_{\mathrm{ST}}$ (bottom row: c and d) versus geographic distance in km between individual plant samples of Honckenya peploides from; (a and c) Mainland Iceland, Surtsey and Heimaey, and (b and d) Surtsey only. Statistical significance was assessed using a Mantel test.

resulting genetic structure on Surtsey and overall patterns of genetic diversity during colonization of oceanic islands for that matter, are more complex than previously thought and are likely driven by a dynamic interaction between multiple spatial, temporal and life history variables. Philipp and Adsersen (2014) describe how ecological conditions for H. peploides have changed during its colonization on Surtsey, and how the changes may affect selective forces.

Facilitated by the species long-distance dispersal capabilities, in this case seed dispersal by sea currents, the colonization of H. peploides on Surtsey started with a few individuals but increased rather quickly to cover most of the empty niches on the island (Sigurdsson and Magnusson, 2010). This development fits the general dynamic model (GDM) of oceanic island biogeography relatively well regarding young and small islands (Whittaker et al., 2008). The distance from mainland Iceland or any other islands in the archipelago $(<35 \mathrm{~km})$ is probably not a barrier to dispersal for this plant. Furthermore, seeds of $\mathrm{H}$. peploides are not prone to desiccation by salt water as the plant is a beach dune halophyte. As a consequence, sufficient gene flow among populations is likely to negate the effects of isolation by distance at the regional scale. At the local scale populations remain significantly differentiated despite their close proximity on both Surtsey and Heimaey, mostly due to short pollen and seed dispersal distances (Philipp and Adsersen, 2014).

The significant genetic distance and differentiation found among the Surtsey populations indicated that the influx of genetic material was likely attributable to multiple introductions from various source locations. Multiple introductions increase both the effective population size and the population growth rate, and have been shown to lead to an increase in gene diversity in newly colonized populations (Dlugosch and Parker, 2008). Therefore, it seems probable that long distance dispersal from multiple locations is a key driver of the current genetic structure on Surtsey. The negative genetic consequences associated with colonization (e.g. founder effects or genetic drift) are likely reduced through the constant influx of new genetic material (Nei et al., 1975; Genton et al., 2005; Stuessy et al., 2012). The maintenance and/or expansion of populations with high gene diversity on the island is then most likely fostered by the following: (a) the vast 
empty niche space available on the island (Fridriksson and Johnsen, 1968); (b) the sea barrier inhibiting establishment of other (probably competing) dispersal groups; (c) the subdioecious breeding system of the plant itself causing poor seed set after self-fertilization (Tsukui and Sugawara, 1992; Eithun, 2003); (d) the ecological conditions during the successional changes of the environment and formation of communities (Phillip and Adsersen, 2014); and (e) the polyploid nature of the study species providing fixed heterozygosity (Soltis and Soltis, 2000). Over its circumpolar distribution range the species is most commonly known as tetraploid with chromosome number of $2 n=4 x=68$ (Löve and Löve, 1975), and Icelandic material was found to be tetraploid as expected (S. H. Árnason, unpublished result).

\subsection{Genetic differentiation among populations and regions}

At the level of intra-island genetic diversity, genetic differentiation $\left(F_{\mathrm{ST}}\right)$ on both the island of Surtsey and on Heimaey was only moderate but highly significant. This indicated some population genetic structure with strong gene flow likely preventing further divergence within the islands (see Franks, 2010). On the other hand, genetic differentiation on mainland Iceland was great, twice as much as the $F_{\mathrm{ST}}$ values of the islands. This indicated a genetic structuring which limited gene flow between the two mainland populations. This strong differentiation is likely due to environmental heterogeneity and differential selection pressures (Pannell and Fields, 2014) as sampling locations on mainland Iceland are much older and separated by a large distance of roughly $85 \mathrm{~km}$. In contrast, sampling locations within Surtsey and Heimaey are quite proximal $(\sim 1$ and $5 \mathrm{~km}$ apart respectively), with limited topography separating them, and in the case of Surtsey, very recently colonized.

Mantel tests of the full data set revealed a positive and highly significant correlation between genetic distance/differentiation and physical distance. This finding is, however, not genetically or phylogeographically informative as the physical distance between regions, especially Iceland vs. Denmark, is too large. However, similar to the migrant model of Slatkins (1987), the non-significant Mantel tests of selected regions and locations indicated that there was significant gene flow between all locations except Denmark. One possible explanation for long distance gene flow between Iceland and Greenland could be seed dispersal via hitchhiking on or in migrating birds. The most likely candidate for this is the light-bellied Brent goose (Branta bernicla subsp. hrota), a shorebird feeding mainly on shore vegetation. This bird winters in Ireland, breeds in the east Canadian High Arctic and undertakes one of the longest migrations of any western Palaearctic goose population, crossing the Greenland Ice Cap, staging at sites in Greenland and Iceland before crossing the North Atlantic to Ireland (Robinson et al., 2004). Light-bellied Brent geese visit Iceland both in spring and autumn, mainly on the west coast but also on the south-western coast including sites investigated in the present study (http://www.ni.is/dyralif/fuglar/). Furthermore, the Light-bellied Brent goose is reported to pass Qeqertarsuaq Island in the autumn and spring having staging sites north of our study locality (Robinson et al., 2004). The geese may consequently disperse seeds of $H$. peploides along their route, including over our sampling site on the south coast of Qeqertarsuaq.

Using only data from Surtsey, Mantel tests (Fig. 3) revealed a negative and non-significant correlation between genetic distance/differentiation and physical distance. This may suggest that at such a small scale, dissimilar genotypes are occurring in close spatial association to one another, similar to that found in other studies (Matesanz et al., 2011; DinizFilho et al., 2013). The breeding system and outcrossing nature of the plant might be keeping inbreeding depression in check via reduced fitness of self-fertilized embryos. In accordance with this, the analysis of molecular variance indicated that despite the clonal capabilities of $H$. peploides, most of the genetic variance was within populations (sampling locations). These results parallel similar studies on $H$. peploides conducted in Spain and Portugal (Sánchez-Vilas et al., 2010). We therefore postulate that the success of dispersal at the regional scale maintains population cohesion and negates the effect of isolation by distance. The outcrossing nature of the plant then acts as a buffer to maintain moderate genetic differentiation at the local scale.

\subsection{Phylogeography of $\mathrm{H}$. peploides in the Iceland regions}

The Surtsey NJ tree (Fig. 2) revealed two distinct clusters which indicated significant genetic structure on the small island. This is likely explained by the relatively young age of the island itself and by multiple colonization events combining genotypes of differentiated populations from the source regions. The original report of plant colonization on the island shows that $H$. peploides initially colonized the northeastern shore (Fridriksson, 1970), including SD and SK sites in the present study. During the summer of 1968 at location SK (F15 in report) there were three plants which had one, four and five branches with 16, 29 and 34 leaves respectively. Likewise, at outermost site SD (B13 in report) there were two plants having only one stem with few leaves each, meaning that they were younger. This indicates different colonization events, possibly at differing times as none of the plants had produced seed yet. A further explanation for the significant genetic distance and differentiation found between sites on the island is that the plants originally colonizing Surtsey were of diverse genetic origin (populations) and that the colonizers that gradually established on the eastern and western part of the island were therefore from different populations in Iceland or from Vestmannaeyjar islands. 
The Bayesian inference clustering (Fig. 1) revealed a clear east-west split in the Surtsey populations. The eastern part of the island was colonized earlier than the western part, around the large crater. The main pathway was from the northern sandy shores up to the eastern lava and then onto the southern part of the island. Another pathway, though minor, was up the gully between the two palagonite hills, where seeds of plants were probably gradually blown and moved along. Two sampling locations on the north-west side of the island of Surtsey (SC and SD), which clustered together genetically, are separated by a distance of up to $800 \mathrm{~m}$ and a $100 \mathrm{~m}$ high volcanic crater. The total area of the island as of 2002 was merely $1.4 \mathrm{~km}^{2}$ (Jakobsson and Gudmundsson, 2003). These sampling locations were colonized at different times: the SD location was colonized first in 1968 and the SC location (I8 in report) was not colonized until after 1978 (Fridriksson, 1982). The genetic similarity of SC and SD could possibly indicate that seed movement and spread of $H$. peploides within the island of Surtsey is being facilitated by wind. Surtsey is a very windy environment and therefore movement of surface sand and seeds occur regularly.

Bayesian analysis of the whole data set was well supported by both the un-rooted NJ trees as well as the MDS analysis. Once again, this, along with the moderate differentiation found, indicated multiple colonization events on Surtsey from several sources as well as a clear genetic split between the Iceland/Greenland and Denmark locations. For the Iceland regions, populations from Gardur (IG), Heimaey (HA and $\mathrm{HB}$ ) and the western region of Surtsey (SC and SD) were clearly differentiated from the eastern group which included populations from Stokkseyri (ST) and the locations on the eastern side of Surtsey (SK, SE and SF). As revealed here by the genetic structure analysis, the colonization of $H$. peploides on Surtsey likely took place from several source locations including Heimaey, and the southern coast of Iceland. Our study indicates that the populations closer to the Reykjanes peninsula (probably more south-eastern coastal sites) and from Heimaey are the most likely source of genetic material for the populations on the western side of Surtsey. The southern shore of mainland Iceland is the most probable source of colonists for the eastern side and the northern sand spit on the island.

Acknowledgements. Research presented here was supported by grants from the Carlsberg Foundation (no. 200901 0713), Icelandic Centre for Research (Rannís no. 121155-0061) and University of Iceland Research Fund (no. 1535-153374). We would like to express our appreciation to the Surtsey Research Society for logistic support and the Icelandic Coast Guard for transport to/from Surtsey. We would like to thank Ruth Bruus Jakobsen from Copenhagen University for scientific and technical contributions. From Iceland, we thank Sigurdur H. Magnússon and Erling Ólafsson for advice and assistance in the field sample collection on Surtsey, Lilja Karlsdóttir and G. Benjamin Leduc for assistance during the initial phase of the research and finally Snorri Baldursson for insightful comments and input that greatly improved the interpretation of results in this paper.

Edited by: B. D. Sigurdsson

\section{References}

Affre, L., Thompson, J. D., and Debussche, M.: Genetic structure of continental and island populations of the Mediterranean endemic Cyclamen balearicum (Primulaceae), Amer. J. Bot., 84, 437-451, doi:10.2307/2446019, 1997.

Alsos, I. G., Ehrich, D., Thuiller, W., Eidesen, P. B., Tribsch, A., Schönswetter, P., Lagaye, C., Taberlet, P., and Brochmann, C.: Genetic consequences of climate change for northern plants, P. R. Soc. B, 279, 2042-2051, doi:10.1098/rspb.2011.2363, 2012.

Baillie, P. W.: Seasonal growth and development of the subarctic plant Honckenya peploides subsp. robusta (Caryophyllaceae) on Niantic Bay, Connecticut, USA, Rhodora, 114, 148-162, doi:10.3119/10-25, 2012.

Barton, N. H. and Mallet, J.: Natural selection and random genetic drift as causes of evolution on islands, Philos. T. R. Soc. B., 351, 785-795, doi:10.1098/rstb.1996.0073, 1996.

Brooks, T. M.: Global biodiversity conservation priorities, Science, 313, 58-61, doi:10.1126/science.1127609, 2006.

Buerki, S., Devey, D. S., Callmander, M. W., Phillipson, P. B., and Forest, F.: Spatio-temporal history of the endemic genera of Madagascar, Bot. J. Linn. Soc., 171, 304-329, doi:10.1111/boj.12008, 2013.

Charlesworth, D. and Charlesworth, B.: Inbreeding depression and its evolutionary consequences, Annu. Rev. Ecol. Syst., 18, 237-268, doi:10.1146/annurev.es.18.110187.001321, 1987.

Chessel, D., Dufour, A.-B., and Thioulouse, J.: The ade4 package-I: one-table methods, R News, 4, 5-10, 2004.

Cody, M. L. and Overton, J. M.: Short-term evolution of reduced dispersal in island plant populations, J. Ecol., 84, 53-61, 1996.

Désamoré A., Laenen, B., González-Mancebo, J. M., Jaén Molina, R., Bystriakova, N., Martinez-Klimova, E., Carine, M. A., and Vanderpoorten, A.: Inverted patterns of genetic diversity in continental and island populations of the heather Erica scoparia s.1., J. Biogeogr., 39, 574-584, doi:10.1111/j.1365-2699.2011.02622.x, 2012.

Diniz-Filho, J. A. F., Soares, T. N., Lima, J. S., Dobrovolski, R., Landeiro, V. L., Telles, M. P. de C., Rangel, T. F., and Bini, L. M.: Mantel test in population genetics, Genet. Mol. Biol., 36, 475-485, doi:10.1590/S1415-47572013000400002, 2013.

Dlugosch, K. M. and Parker, I. M.: Founding events in species invasions: genetic variation, adaptive evolution, and the role of multiple introductions, Mol. Ecol., 17, 431-449, doi:10.1111/j.1365294X.2007.03538.x, 2008.

Ehrich, D.: AFLPDAT: a collection of $r$ functions for convenient handling of AFLP data, Mol. Ecol. Notes, 6, 603-604, doi:10.1111/j.1471-8286.2006.01380.x, 2006.

Eidesen, P. B., Ehrich, D., Bakkestuen, V., Alsos, I. G., Gilg, O., Taberlet, P., and Brochmann, C.: Genetic roadmap of the Arctic: plant dispersal highways, traffic barriers and capitals of diversity, New Phytol., 200, 898-910, doi:10.1111/nph.12412, 2013. 
Einarsson, E.: Report on dispersal of plants to Surtsey, in: Surtsey Res. Progr. Rep. I, 16-18, 1965.

Einarsson, E.: Comparative ecology of colonizing species of vascular plants, in: Surtsey Res. Progr. Rep. IV, 9-21, 1968.

Eithun, A.: Reproduction, Genetic Variation and Responses to Temperature Increase in Populations of Honckenya peploides, Master's thesis, University of Oslo, 2003.

Ellstrand, N. C. and Schierenbeck, K. A.: Hybridization as a stimulus for the evolution of invasiveness in plants?, P. Natl. Acad. Sci. USA, 97, 7043-7050, doi:10.1073/pnas.97.13.7043, 2000.

Evanno, G., Regnaut, S., and Goudet, J.: Detecting the number of clusters of individuals using the software STRUCTURE: a simulation study, Mol. Ecol., 14, 2611-2620, doi:10.1111/j.1365294X.2005.02553.x, 2005.

Excoffier, L. and Lischer, H. E. L.: Arlequin suite ver 3.5: a new series of programs to perform population genetics analyses under Linux and Windows, Mol. Ecol. Resour., 10, 564-567, doi:10.1111/j.1755-0998.2010.02847.x, 2010.

Felsenstein, J.: PHYLIP - Phylogeny Inference Package (version 3.2), Cladistics, 5, 164-166, doi:10.1111/j.10960031.1989.tb00562.x, 1989.

Fernández-Mazuecos, M. and Vargas, P.: Genetically depauperate in the continent but rich in oceanic islands: Cistus monspeliensis (Cistaceae) in the Canary Islands, PLoS ONE, 6, e17172, doi:10.1371/journal.pone.0017172, 2011.

Foll, M., Fischer, M. C., Heckel, G., and Excoffier, L.: Estimating population structure from AFLP amplification intensity, Mol. Ecol., 19, 4638-4647, doi:10.1111/j.1365-294X.2010.04820.x, 2010.

Frankham, R.: Do island populations have less genetic variation than mainland populations?, Heredity, 78, 311-327, doi:10.1038/hdy.1997.46, 1997.

Frankham, R.: Inbreeding and extinction: island populations, Conserv. Biol. Ser., 12, 665-675, doi:10.1111/j.15231739.1998.96456.x, 1998.

Franks, S. J.: Genetics, evolution, and conservation of island plants, J. Plant Biol., 53, 1-9, doi:10.1007/s12374-009-9086-y, 2010.

Fridriksson, S.: The colonization of vascular plants on Surtsey in 1968, in: Surtsey Res. Progr. Rep. V, 10-14, 1970.

Fridriksson, S.: Vascular plants on Surtsey 1977-1980, in: Surtsey Res. Progr. Rep. IX, 46-58, 1982.

Fridriksson, S. and Johnsen, B.: The colonization of vascular plants on Surtsey in 1967, in: Surtsey Res. Progr. Rep. IV, 31-38, 1968.

Fridriksson, S. and Magnússon, B.: Development of the ecosystem on Surtsey with references to Anak Krakatau, GeoJournal, 28, 287-291, doi:10.1007/BF00177242, 1992.

Genton, B. J., Shykoff, J. A., and Giraud, T.: High genetic diversity in French invasive populations of common ragweed, Ambrosia artemisiifolia, as a result of multiple sources of introduction, Mol. Ecol., 14, 4275-4285, doi:10.1111/j.1365294X.2005.02750.x, 2005.

Holderegger, R., Stehlik, I., Lewis Smith, R. I., and Abbott, R. J.: Populations of Antarctic Hairgrass (Deschampsia antarctica) show low genetic diversity, Arct. Antarct. Alp. Res., 35, 214-217, 2003.

Hultén, E.: Flora of Alaska and Neighboring Territories: a Manual of the Vascular Plants, Stanford University Press, Stanford, California, ISBN: 0-8047-0643-3, 1968.
Hultén, E. and Fries, M.: Atlas of North European Vascular Plants, Koeltz Scientific Books, Köningstein, Germany, ISBN: 3-87429263-0, 1986.

Husband, B. C. and Barrett, S. C. H.: Colonization history and population genetic structure of Eichhornia paniculata in Jamaica, Heredity, 66, 287-296, 1991.

Jaenike, R.: A steady state model of genetic polymorphism on islands, Am. Nat., 107, 793-795, 1973.

Jakobsson, M. and Rosenberg, N. A.: CLUMPP: a cluster matching and permutation program for dealing with label switching and multimodality in analysis of population structure, Bioinformatics, 23, 1801-1806, doi:10.1093/bioinformatics/btm233, 2007.

Jakobsson, S. P. and Gudmundsson, G.: Rof Surtseyjar. Mælingar 1967-2002 og framtídarspá (The marine abrasion of Surtsey, Iceland: Area changes 1967-2002 and future development), Náttúrufrædingurinn, 71, 138-144, 2003.

Keller, S. R. and Schwaegerle, K. E.: Maternal sex and mate relatedness affect offspring quality in the gynodioecious $\mathrm{Si}$ lene acaulis, J. Evol. Biol., 19, 1128-1138, doi:10.1111/j.14209101.2006.01101.x, 2006.

Kruskal, J. B.: Nonmetric multidimensional scaling: a numerical method, Psychometrika, 29, 115-129, doi:10.1007/BF02289694, 1964.

Löve, Á. and Löve, D.: Cytotaxonomical Atlas of the Arctic Flora, J. Cramer, Vaduz, Germany, doi:10.1017/S0376892900019202, 1975.

Lynch, M. and Milligan, B. G.: Analysis of population genetic structure with RAPD markers, Mol. Ecol., 3, 91-99, doi:10.1111/j.1365-294X.1994.tb00109.x, 1994.

MacArthur, W. and Wilson, O. E.: The Theory of Island Biogeography, Princeton University Press, ISBN: 0-691-08836-5, 1967.

Magnússon, B., Magnússon, S. H., and Fridriksson, S.: Developments in plant colonization and succession on Surtsey during 1999-2008, Surtsey Res., 12, 57-76, 2009.

Magnússon, B., Magnússon, S. H., Ólafsson, E., and Sigurdsson, B. D.: Plant colonization, succession and ecosystem development on Surtsey with reference to neighbouring islands, Biogeosciences, 11, 5521-5537, doi:10.5194/bdg-11-5521-2014, 2014.

Malling, H.: The chromosome number of Honckenya peploides (L.) EHRH., with a note on its mode of sex determination, Hereditas, 43, 517-524, doi:10.1111/j.1601-5223.1957.tb03454.x, 1957.

Matesanz, S., Gimeno, T. E., de la Cruz, M., Escudero, A., and Valladares, F.: Competition may explain the fine-scale spatial patterns and genetic structure of two co-occurring plant congeners: spatial genetic structure of congeneric plants, J. Ecol., 99, 838-848, doi:10.1111/j.1365-2745.2011.01812.x, 2011.

Meudt, H. M. and Clarke, A. C.: Almost forgotten or latest practise? AFLP applications, analyses and advances, Trends Plant Sci., 12, 106-117, doi:10.1016/j.tplants.2007.02.001, 2007.

Nei, M.: Analysis of gene diversity in subdivided populations, P. Natl. Acad. Sci. USA, 70, 3321-3323, PMID: 4519626, 1973.

Nei, M., Maruyama, T., and Chakraborty, R.: The bottleneck effect and genetic variability in populations, Evolution, 29, 1-10, 1975

Novak, S. J. and Mack, N. N.: Genetic variation in Bromus tectorum (Poaceae): comparison between native and introduced populations, Heredity, 71, 167-176, doi:10.1038/hdy.1993.121, 1993.

Pannell, J. R. and Fields, P. D.: Evolution in subdivided plant populations: concepts, recent advances and future directions, New Phytol., 201, 417-432, doi:10.1111/nph.12495, 2014. 
Philipp, M., and Adsersen, H. E.: Colonization of an empty island: how does a plant with a plastic gender system respond?, Biogeosciences Discuss., 11, 2014.

Pineiro, R. A., Aguilar, J. F., Munt, D. D., and Feliner, G. N.: Ecology matters: Atlantic-Mediterranean disjunction in the sanddune shrub Armeria pungens (Plumbaginaceae), Mol. Ecol., 16, 2155-2171, doi:10.1111/j.1365-294X.2007.03280.x, 2007.

Poczai, P., Varga, I., Laos, M., Cseh, A., Bell, N., Valkonen, J. P. T., and Hyvönen, J.: Advances in plant gene-targeted and functional markers: a review, Plant Methods, 9, 6, doi:10.1186/1746-48119-6, 2013.

Powell, W., Morgante, M., Andre, C., Hanafey, M., Vogel, J., Tingey, S., and Rafalski A.: The comparison of RFLP, RAPD, AFLP and SSR (microsatellite) markers for germplasm analysis, Mol. Breeding, 2, 225-238, doi:10.1007/BF00564200, 1996.

Pritchard, J. K., Stephens, M., and Donnelly, P.: Inference of population structure using multilocus genotype data, Genetics, 155, 945-959, PMID: 10835412, 2000.

Robinson, J. A., Colhoun, K., Gudmundsson, G. A., Boertmann, D., Merne, O. J., O'Briain, M., Portig, A. A., Mackie, K., and Boyd, H.: Light-bellied Brent Goose Branta bernicla hrota (East Canadian High Arctic population) in Canada, Ireland, Iceland, France, Greenland, Scotland, Wales, England, the Channel Islands and Spain 1960/61-1999/2000, Waterbird Review Series, The Wildfowl and Wetlands Trust/Joint Nature Conservation Committee, Slimbridge, ISBN 0900806 49 4, 2004.

Rosenberg, N. A.: DISTRUCT: a program for the graphical display of population structure, Mol. Ecol. Notes, 4, 137-138, doi:10.1046/j.1471-8286.2003.00566.x, 2004.

Sakai, A. K., Allendorf, F. W., Holt, J. S., Lodge, D. M., Molofsky, J., With, K. A., Baughman, S., Cabin, R. J., Cohen, J. E., Ellstrand, N. C., McCauley, D. E., O'Neil, P., Parker, I. M., Thompson, J. N., and Weller, S. G.: The population biology of invasive species, Annu. Rev. Ecol. Syst., 32, 305-332, doi:10.1146/annurev.ecolsys.32.081501.114037, 2001.

Sánchez-Vilas, J., Philipp, M., and Retuerto, R.: Unexpectedly high genetic variation in large unisexual clumps of the subdioecious plant Honckenya peploides (Caryophyllaceae), Plant Biol., 12, 518-525, doi:10.1111/j.1438-8677.2009.00231.x, 2010.

Savolainen, V., Anstett, M. C., Lexer, C., Hutton, I., Clarkson, J. J., Norup, M. V., Powell, M. P., Springate, D., Salamin, N., and Baker, W. J.: Sympatric speciation in palms on an oceanic island, Nature, 441, 210-213, doi:10.1038/nature04566, 2006.

Schönswetter, P., Stehlik, I., Holdergger, R., and Tribsch, A.: Molecular evidence for glacial refugia of mountain plants in the European Alps, Mol. Ecol., 14, 3547-3555, doi:10.1111/j.1365294X.2005.02683.x, 2005.

Sigurdsson, B. D. and Magnusson, B.: Effects of seagulls on ecosystem respiration, soil nitrogen and vegetation cover on a pristine volcanic island, Surtsey, Iceland, Biogeosciences, 7, 883-891, doi:10.5194/bg-7-883-2010, 2010.

Slatkin, M.: Gene flow and the geographic structure of natural populations, Science, 236, 787-792, doi:10.1126/science.3576198, 1987.

Soltis, P. S. and Soltis, D. E.: The role of genetic and genomic attributes in the success of polyploids, P. Natl. Acad. Sci. USA, 97, 7051-7057, doi:10.1073/pnas.97.13.7051, 2000.

Stuessy, T. F., Takayama, K., and López-Sepúlveda, P.: Founder effects are invisible in endemic species of oceanic islands, J. Bio- geogr., 39, 1565-1566, doi:10.1111/j.1365-2699.2012.02768.x, 2012.

Su, Y., Wang, T., and Deng, F.: Contrasting genetic variation and differentiation on Hainan Island and the Chinese mainland populations of Dacrycarpus imbricatus (Podocarpaceae), Biochem. Syst. Ecol., 38, 576-584, doi:10.1016/j.bse.2010.07.003, 2010.

Tamura, K., Stecher, G., Peterson, D., Filipski, A., and Kumar, S.: MEGA6: Molecular Evolutionary Genetics Analysis Version 6.0, Mol. Biol. Evol. 30, 2725-2729, doi:10.1093/molbev/mst197, 2013.

Thórarinsson, S.: The Surtsey eruption, course of events and the development of Surtsey and other new islands, in: Surtsey Res. Progr. Rep. II, 117-123, 1966.

Thórsson, Æ. Th., Pálsson, S., Lascoux, M., and AnamthawatJónsson, K.: Introgression and phylogeography of Betula nana (diploid), B. pubescens (tetraploid) and their triploid hybrids in Iceland inferred from cp-DNA haplotype variation, J. Biogeogr. 37, 2098-2110, doi:10.1111/j.1365-2699.2010.02353.x, 2010.

Triantis, K. A, Borges, P. A. V., Ladle, R. J., Hortal, J., Cardoso, P., Gaspar, C., Dinis, F., Mendonca, E., Silveira, L. M. A., Gabriel, R., Melo, C., Santos, A. M. C., Amorim, I. R., Ribeiro, S. P., Serrano, A. R. M., Quartau, J. A., and Whittaker, R. J.: Extinction debt on oceanic islands, Ecography, 33, 285-294, doi:10.1111/j.1600-0587.2010.06203.x, 2010.

Tsukui, T. and Sugawara, T.: Dioecy in Honckenya peploides var. Major (Caryophyllaceae), Bot. Mag. Tokyo, 105, 615-624, 1992.

Tsuyuzaki, S.: Causes of plant community divergence in the early stages of volcanic succession, J. Veg. Sci., 20, 959-969, doi:10.1111/j.1654-1103.2009.01104.x, 2009.

Vekemans, X., Beauwens, T., Lemaire, M., and Roldán-Ruiz, I.: Data from amplified fragment length polymorphism (AFLP) markers show indication of size homoplasy and of a relationship between degree of homoplasy and fragment size, Mol. Ecol., 11, 139-151, doi:10.1046/j.0962-1083.2001.01415.x, 2002.

Vos, P., Hogers, R., Bleeker, M., Reijans, M., van de Lee, T., Hornes, M., Frijters, A., Pot, J., Peleman, J., Kuiper, M., and Zabeau, M.: AFLP: a new technique for DNA fingerprinting, Nucleic Acids Res., 23, 4407-4414, doi:10.1093/nar/23.21.4407, 1995.

Westerbergh, A., and Saura, A.: Genetic differentiation in endemic Silene (Caryophyllaceae) on the Hawaiian Islands. Amer. J. Bot., 81, 1487-1493, doi:10.2307/2445321, 1994.

Whittaker, R. J., Triantis, K. A., and Ladle, R. J.: A general dynamic theory of oceanic island biogeography, J. Biogeogr., 35, 977-994, doi:10.1111/j.1365-2699.2008.01892.x, 2008.

Wright, S.: Breeding structure of populations in relations to speciation, Am. Nat., 74, 232-248, 1940.

Wright, S.: The interpretation of population structure by $\mathrm{F}$ statistics with special regard to systems of mating, Evolution, 19, 395-420, doi:10.2307/2406450, 1965.

Yamada, T. and Maki, M.,: Impact of geographical isolation on genetic differentiation in insular and mainland populations of Weigela coraeensis (Caprifoliaceae) on Honshu and the Izu Islands, J. Biogeogr., 39, 901-917, doi:10.1111/j.13652699.2011.0263.x, 2012. 